\title{
MONITORING OF AGRICULTURAL LANDSCAPE IN NORWAY
}

\author{
H.G. Wallin, G. Engan \\ Norwegian Forest and Landscape Institute, p.b. 115, N-1431 Ås, Norway - (hgw, gue)@ skogoglandskap.no
}

KEY WORDS: Agriculture, Resources, Monitoring, Change Detection, Aerial, Stereoscopic.

\begin{abstract}
:
An overall societal aim is to ensure a sustainable use and management of agricultural landscapes. This requires continuous delivery of reliable and up-to-date information to decision-makers. To be able to deliver this information, a monitoring program for agricultural landscapes was initiated in Norway 13 years ago. The program documents and reports on land use / land cover changes from data captured through interpretation of true colour aerial photos using stereo instruments. The monitoring programme is based on a sample of 1000 squares of $1 \times 1 \mathrm{~km}$ and the entire sample of squares is photographed over a five-year period. Each square is then mapped repeatedly every fifth year to record changes.

Aerial photo interpretation is based on a custom classification system which is built up hierarchically, with three levels. The first level comprises seven land type classes: Agricultural land, Bare ground, Semi-natural open vegetation, Unforested wetland vegetation, Forest, Urban areas and Water. These land classes are further divided into 24 land types at level two, and approximately 100 land types at level 3. In addition to land type units we map both line elements like stone fences and point elements like buildings and solitary threes. By use of indicators that describe status and change focusing on themes of particular policy interest, we can report on whether policy aims are being fulfilled or not. Four indicator themes have been in focus hitherto: landscape spatial structure, biological diversity, cultural heritage and accessibility.

Our data is stored in databases and most of the data quality check/structure process and analyses are now being made in open source software like PostGIS and PostSQL. To assess the accuracy of the photo-interpretation, ground truthing is carried out on $10 \%$ of the squares. The results of this operation document the benefits of having access to photos of the same area from two different years.

The program is designed first and foremost to provide reliable statistics at a national level but the aim is also to report at regional levels - for example for counties or for agricultural landscape regions. The national coverage and application of standardized methods enable frequent updating. This method is cost effective and enables us to quantify changes in landscape qualities as well as adapting the programme to take account of e.g. new findings on relevant indicators.
\end{abstract}

\section{INTRODUCTION}

\subsection{Landscape monitoring}

To ensure a sustainable use and management of agricultural landscape the decision-makers need reliable and up-to-date information. Interpretation of land use / land cover from aerial photos plays a major role in studies of landscape changes in Norway.

A monitoring program where the main aim is to register this changes started in 1998. This program is based on a sample of 1000 squares of $1 \times 1 \mathrm{~km}$. The squares are photographed each fifth year and the land use / land cover situation is digitized in stereo with a classification system that covers area, lines, points and accessibility (Strand, 2002).

By use of indicators that describe status and change focusing on themes of particular policy interest, we can report on whether policy aims are being fulfilled or not. Four indicator themes have been in focus hitherto: landscape spatial structure, biological diversity, cultural heritage and accessibility.

Cultural heritage from existing register is displayed in the stereo model so that the interpreter will update the situation for each element that is registered. A lot of the cultural heritage (as barrows) is hidden by trees. The classification system gives the interpreter the opportunity to use different types of codes describing the situation.
Several controls are carried out on the captured data, e.g. illegal codes and missing features. $10 \%$ of the squares are checked through a field control.

\section{METHODES}

\subsection{Photos}

The mapping is done by the means of stereo instruments and true color photos. Since the program started in 1998 analogue instruments have been replaced with digital instruments. The airborn cameras have also changed from film based to digital CCD. This has improved the quality of the aerial images incredibly.

To interpret a photo there are some things you need to know. The date the photo is taken is very important. The nature looks differently in spring, summer and early autumn. There are also different types of farming in different parts of Norway, so the operator needs to know where in the country the photo is taken. A real challenge is to distinguish between the different stages and activities: from full activity to abandonedfarms.

The scale of the photos has also changed over the period of registration. In Norway we now have a national program for full photo cover with an interval of five to six years. The agricultural monitoring program (3Q) has decided to use these photos because of the cost-effectiveness. The ground sample distance (GSD) varies from 30 to $50 \mathrm{~cm}$. 


\subsection{Classification systems}

The classification system was developed based on what is possible to interpret from an aerial image and the needed of indicators describing the changes in the agricultural landscape. The classification for area is built up hierarchically with three levels for land type classes.

\begin{tabular}{|c|c|}
\hline \multicolumn{2}{|l|}{ A Agricultural land } \\
\hline & $\begin{array}{l}\text { A1 Fields of annual agricultural } \\
\text { plants, and cultivated meadows }\end{array}$ \\
\hline & A2 Horticultural land \\
\hline & A3 Pasture \\
\hline & $\begin{array}{l}\text { A4 Pasture and hay meadows } \\
\text { apparently no longer in use }\end{array}$ \\
\hline \multicolumn{2}{|l|}{$\begin{array}{l}\text { B Natural bare } \\
\text { ground }\end{array}$} \\
\hline & B1 Bare rocks, boulders and scree \\
\hline & B2 Gravel, sand, earth and peat \\
\hline \multirow[t]{6}{*}{$\begin{array}{l}\text { F Permantent } \\
\text { unforested dry-land } \\
\text { vegetation }\end{array}$} & \\
\hline & F1 Semi-natural grassland \\
\hline & F2 Heaths and ridges \\
\hline & F3 Maritim vegetation \\
\hline & F4 Cleared forest \\
\hline & F5 Outfield pasture \\
\hline \multirow[t]{3}{*}{$\begin{array}{ll}\text { M } & \text { Natural, } \\
\text { unforested } & \text { wetland } \\
\text { vegetation } & \\
\end{array}$} & \\
\hline & $\begin{array}{l}\text { M1 Mire and other freshwater } \\
\text { wetlands }\end{array}$ \\
\hline & 2 Salt and brackish wetlands \\
\hline \multirow[t]{4}{*}{$\begin{array}{l}\text { S Forest and three- } \\
\text { covered land }\end{array}$} & \\
\hline & S1 Deciduous forest \\
\hline & S2 Mixed forest \\
\hline & S3 Coniferous forest \\
\hline \multicolumn{2}{|l|}{ U Built-up areas } \\
\hline & U1 Transport \\
\hline & U2 Buildings \\
\hline & $\begin{array}{l}\text { U3 Storage areas, dumps and } \\
\text { rubbish tips }\end{array}$ \\
\hline & $\begin{array}{l}\text { U4 Urban greenways, sport and } \\
\text { recreation areas }\end{array}$ \\
\hline & U5 Other built-up areas \\
\hline \multirow[t]{4}{*}{$\begin{array}{l}\text { V Water, snow and } \\
\text { ice }\end{array}$} & \\
\hline & V1 Freshwater \\
\hline & V2 Snow and ice \\
\hline & V3 Saltwater and brackish water \\
\hline
\end{tabular}

Table 1. Classification system for land type classes for the Norwegian land use / land cover monitoring program.

Interpreted lines are: path, stone wall, fence, line of trees, line of bushes, vegetation line, ditch / canal, stream and high tension cable.

Interpreted points are: pile of stones, boulder, solitary tree, post in field, pylon, building, ruin and fish racks.

Some of these are indicators for biodiversity and some are indicators for the experience of the landscape.

For the accessibility we interpret pedestrian zone , path and road. The size of the square has proved to be too small to tell the accessibility in the agricultural landscape, but the changes can be measured and inaccessible areas are visible.

\subsection{Software systems}

For the interpretation Summit software with a Planar mirror stereo view system is used. MicroStation is used for mapping.

The data is converted into sosi-files (the Norwegian standard for vector data) and these sosi-files are checked for errors.

Further quality check, storage and analyses of the data are now being carried out with the open source software PostgreSQL and PostGIS.

\subsection{Field control}

$10 \%$ of the squares are visited in the field and are used to verify the interpretation. The program are now in the second inventory cycle. The operator's interpretation has improveddue to several reasons: the photos are better, the skills of the interpreter have improved and the operators easier understand what they see on the ground when they can compare two photos with different dates. They see and understand the development of the area better (Engan, 2012)

\begin{tabular}{|c|c|c|}
\hline & $\begin{array}{c}\text { Second } \\
\text { recording }\end{array}$ & $\begin{array}{c}\text { First } \\
\text { recording }\end{array}$ \\
\hline Type of area & $\%$ & $\%$ \\
\hline A1 Annual agricultural plants & 97,4 & 95,2 \\
\hline A2 Horticultural land & 100,0 & 82,4 \\
\hline A3 Pasture & 72,8 & 68,1 \\
\hline $\begin{array}{l}\text { A4 Pasture and hay meadows } \\
\text { apparently no longer in use }\end{array}$ & 56,3 & 51,5 \\
\hline B1 Bare rock, boulders, scree & 96,0 & 55,6 \\
\hline B2 Gravel, sand, earth, peat & 100,0 & 90,0 \\
\hline F1 Semi-natural grassland & 53,3 & 52,2 \\
\hline F2 Heaths and ridges & 67,5 & 59,4 \\
\hline F3 Seashore vegetation & 50,0 & \\
\hline F4 Cleared forest & 84,4 & 77,6 \\
\hline F5 Outfield pasture & 29,5 & \\
\hline M1 Mire, freshwater wetlands & 81,2 & 67,2 \\
\hline S1 Decidous forest & 67,7 & 63,9 \\
\hline S2 Mixed forest & 61,0 & 29,1 \\
\hline S3 Coniferous forest & 42,3 & 75,1 \\
\hline U1 Transport & 99,0 & 75,9 \\
\hline U2 Buildings & 98,2 & 89,8 \\
\hline U3 Storage areas, dumps, rubbish tips & 71,4 & 43,8 \\
\hline $\begin{array}{lcl}\text { U4 Urban greenways, sport-, } \\
\text { recreation areas }\end{array}$ & 90,9 & 79,7 \\
\hline U5 Other built-up areas & 100,0 & 82,9 \\
\hline V1 Freshwater & 99,1 & 91,0 \\
\hline V3 Salt- and brackish water & 99,2 & 99,6 \\
\hline SUM & 77,3 & 76,2 \\
\hline
\end{tabular}

Table 2: Results from field control for first and second inventory cycle. 
All classes (except coniferous forest) have better result of correct interpretation in the second cycle. For example A1 Annual agricultural plants has a correct interpretation of $97 \%$, but still some classes has a low rate of correct interpretation.

A3 Pasture has a correct interpretation in $73 \%$ of the cases. The operator often interpret this areas as A1 Full cultivated areas (10 $\%)$ and A4 Pasture and hay meadows apparently no longer in use $(6 \%)$. The rest $(9 \%)$ are placed in several different classes. The conclusion is that the time of the photo is extremely important. The area need to be characterised by grazing and photos from early spring and summer often miss this character.

A4 Pasture and hay meadows apparently no longer in use has a correct interpretation of $56 \%$. The interpretation has increased from $52 \%$ in first cycle. The operator explains this improvement with the possibility of looking at images from two different dates which makes it easier to understand the development of the area.

F1 Semi-natural grassland is a class that is considerably influenced by human activities, but which is not clearly grazed or cut. The area is usually directly associated with agricultural land and buildings. Investigation of the material shows that this area is misinterpreted as A4 Pasture and hay meadows apparently no longer in use (16\%) and A3 Pasture (11.5\%). This reflects the difficulties with overgrown area in or out of use.

F5 Outfield pasture is the class the operators find most difficulty to interpret. The grazing is not intensive and the operator needs some signs like high proportion of grass and herbs, pathways or animals in the terrain. A detailed review shows that $30 \%$ of the misinterpretation is into the classes A3 Pasture and A4 Pasture and hay meadows apparently no longer in use, $25 \%$ are misinterpreted as F2 Heats and ridges. As a follow-up of the poor result the next field work area for calibrating, the operators will have focus mainly on outfield pasture.

\section{ANALYSES}

The monitoring program's main aim is to ensure a sustainable use and management of the agricultural landscape. We produce statistics at both national and regional level. To show the development of the agricultural landscape and the differences between the regions in Norway, we use different indicators.

This is an example of visualizing regional differences with a radar chart.

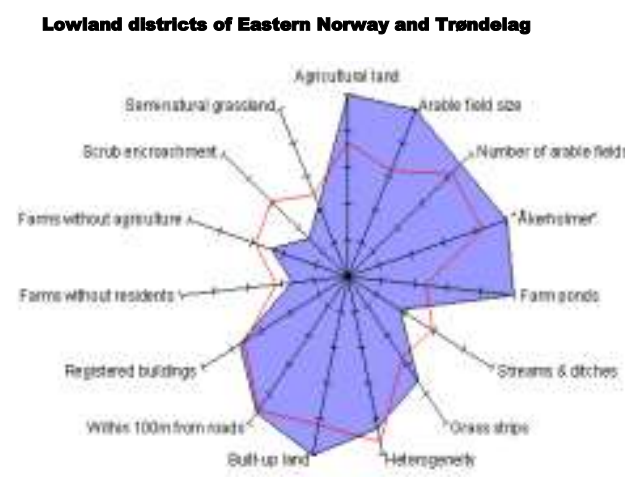

Figure 1. Lowland districts of Eastern Norway and the county Troendelag. The red line is the average of the country and the blue is the condition in these districts. The chart shows that these districts have more agricultural land than the average of the country. It is also more built-up area than the country average.

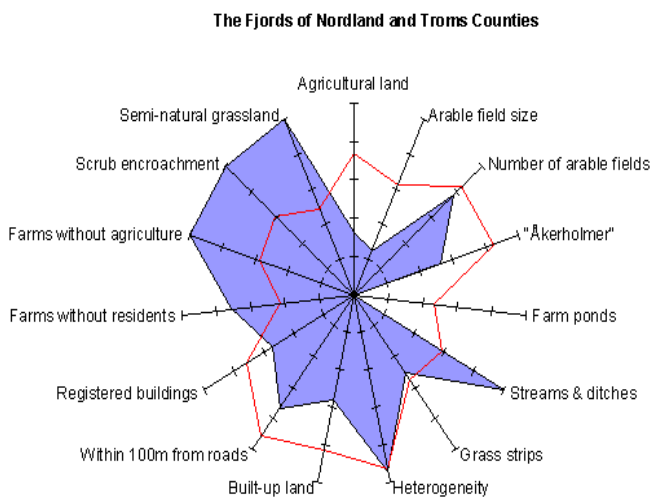

Figure 2. Fjord districts of the counties Nordland and Troms. The red line is the average of the country and the blue is the condition in these districts. The northern district of Norway has a climate that makes the agricultural land very small. This chart also shows that there are a lot of farms without agriculture and without residents. The depopulation is high in these district.

\section{CONCLUSIONS}

The opportunity to see two images from different dates covering the same area gives the operator a greater understanding of what he / she sees and an better ability to interpret the land use. The quality of the photos, information of where in the country the photo is taken and the photo-date is crucial in order to interpretate the areas correctly.

Field control of photo interpretation is very important to be able to highlight the uncertainty of the data. The analysis can then merge classes or pay attention to misinterpretation in a more correct manner.

\section{References from Other Literature.}

Strand, G-H. , Dramstad, W., Engan, G., 2002. The effect of field experience on the accuracy of identifying land cover types in aerial photographs. International journal of Applied Earth Observation and Geoinformation 4 (2002), pp. 137-146.

Engan, G., 2012. 3Q - feltkontroll av flybildetolking for årene 2004-2008. Skog og landskap, 2012.

Dramstad, W., Fjellstad, W., Puschmann, O., 2003. 3Q Tilstandsovervåking og resultatkontroll i jordbrukets kulturlandskap. NIJOS, Report, 11/03.

http://www.skogoglandskap.no/publikasjon/nj_rapport_11_03 